\title{
ARTICLES
}

\section{REGIONAL ECONOMIC COOPERATION IN NORTHEAST ASIA}

\section{Ts. Batbayar}

In the political meaning, Northeast Asia consists of the six countries of Japan, South Korea (Republic of Korea), North Korea (Democratic People's Republic of Korea), Russia, China, and Mongolia. When we talk about economic cooperation in this region, in addition to Japan, South and North Korea, and Mongolia, we limit the scope to China's Northeastern provinces of Liaoning, Jilin, and Heilongjiang (with the possible inclusion of Inner Mongolia), and Russia's Far East, comprising Eastern Siberia and the Maritime Province.

\section{The Current State of Cooperation}

Northeast Asia has abundant natural resources and tremendous economic potential. Many people share this view, but there is yet neither single agreedupon view of regional economic development nor, most importantly of an institutional framework for regional cooperation.

What are the inducements to promote economic cooperation in this region? It is widely recognized that Japan and South Korea have an advantage in capital and modern technology, China has abundant labor, the Russian Far East and Mongolia have rich natural resources, and North Korea is regarded as having a large labor force. Such a strong complementarily of production factors suggests that the development of regional economic cooperation will bring mutual benefits to all in this region.

\section{Complementarily of Production Factors in Northeast Asia}

Table 1.

Resource Labor Capital Technology Management

$\begin{array}{llllll}\text { Northeast China } & \text { A } & \text { AA } & \text { S } & \text { SS } & \text { SS } \\ \text { Russian Far East } & \text { AA } & \text { SS } & \text { SS } & \text { SS } & \text { SS } \\ \text { North Korea } & \text { A } & \text { A } & \text { SS } & \text { SS } & \text { SS } \\ \text { Mongolia } & \text { A } & \text { S } & \text { SS } & \text { SS } & \text { SS } \\ \text { South Korea } & \text { SS } & \text { S } & \text { A } & \text { A } & \text { A } \\ \text { Japan } & \text { SS } & \text { S } & \text { AA } & \text { AA } & \text { AA }\end{array}$

$A A=$ Very abundant; $A$-Abundant $S=$ Scarce; $S S==$ Very scarce 
What arc the constraints on economic cooperation in this region? The most characteristic fact in this region is that the gross domestic product (GDP) varies enormously. Table 2 shows that South Korea's GDP is less than one-tenth of Japan's, and that the combined GDP of Northeast China and the Russian Far East accounts for less than one-fiftieth of that of Japan. Put differently, Japan's share is about $90 \%$ of the total regional GDP

\section{General Economic Data of Northeast Asia}

Table 2.

$\begin{array}{lllc} & \begin{array}{l}\text { GDP } \\ \text { (US S Billion) }\end{array} & \begin{array}{l}\text { Population } \\ \text { (million) }\end{array} & \begin{array}{c}\text { Percept GDP } \\ \text { (USS) }\end{array} \\ \text { Northeast China } & 38.2 & 99.9 & 382 \\ \text { Russian Far East } & 19.4 & 8.0 & 2,411 \\ \text { North Korea } & 21.5 & 21.8 & 986 \\ \text { Mongolia } & 1.9 & 2.2 & 780 \\ \text { South Korea } & 239.7 & 43.2 & 5,549 \\ \text { Japan } & 3,123.5 & 123.8 & 25,230 \\ \text { Total NEA } & 3,442.3 & 296.7 & 11,600 \\ \text { USA (1990) } & 5,392.0 & 250.0 & 21,568 \\ \text { Canada(1990) } & 570.0 & 26.5 & 21,509 \\ \text { USSR } & 691.8 & 289.0 & 2,394 \\ \text { China } & 338.8 & 1,151.3 & 294\end{array}$

Source: Burnham O. Campbell. "Regional comparative advantage in Northeast Asia: Determinants of the present structure and some future possibilities, "August 2S27'. 1992. Vladivostok. Russia. Table 1 I

It is well known that huge differences among national GNPs make it extremely difficult to establish a regional cooperative organization. If regional trade could be rapidly increased, it would be possible to promote some kind of cooperation. As available trade statistics show, Japan, South Korea and China play the dominant role in regional trade, with some interesting changes in recent years, such as rapidly growing trade between South Korea and China, and increased border trade between China and some successor states to the former Soviet Union. It should be pointed out, however, that so far the trade linkage degree in this region has not increased.

We also witness the emergence of what Robert A. Scaloppini has termed Natural Economic Territories (NETS), entities that cross political boundaries, often

Encompassing only portions of states, but with their raison d'кtre resting upon the combination of natural resources, manpower, technology, and capital that can be pooled to maximum advantage. The private sector is the truly critical 
element in the creation of Nets. In the coming years, several Nets might emerge in North-east Asia, including Shandong-South Korea, the Tureen River basin, the Sea of Japan rim, and Sakhalin-Kuriles-Japan.

\section{Urgent Problems}

1.How to build an adequate infrastructure. The largest obstacle in the path toward forming a Northeast Asian economic zone is an inadequate physical infrastructure, including railways, roads, ports, airports, and telecommunication facilities. To overcome this obstacle, international cooperation is required in technology, research, and funding.

In this regard, the proposed Tumen River project serves as a good example. No fewer than three separate plans have so far been formulated. China's development plan for this area calls for the construction of an international port at Fanchuang in Hunchun, Jilin province, and the designation of this area as a free trade zone. This plan includes the development of the surrounding area, the "Golden Delta," connecting the prefecture seat Yanji, Vladivostok, and Chongjin in North Korea. In other words, the master plan intends to develop this area as the center of the Japan Sea Rim by combining the resources of the Russian Far East, the labor force of China and North Korea, and the capital and technology of Japan and South Korea.

North Korea welcomed this idea and declared its own development plan it includes the opening of the three northern ports of Sonbong, Rajin, and Chongjin. The North Korean plan also anticipates the development of 195 out of the 621 square kilometers of the Rajin-Sonbong region, and it expects a large amount of money for infrastructure development.

Russia, the other country that shares the Tumen River delta, has also announced a development plan for this area. This plan was drawn up by the United Nations Industrial Development Organization (UNIDO) as the "Greater Vladivostok Free Economic Zone Plan". The basic aim of this plan is to open the coastal area around Vladivostok and Nakhodka to foreign investment, and to integrate the Russian Far East with the Asia-Pacific economic zone. At present, the plans of these countries differ in their respective goals. However, it is worth noting that all countries concerned have recognized the importance of this area and have started development planning.

Building an infrastructure requires cooperation from governments, but funding and technology can come from private investment and joint ventures. A privately supported Siberian development project is already under way, but its ultimate success hinges on a broad consensus among all nations concerned. 
Some people have proposed a giant long-term project to increase energy supplies for a huge area covering Siberia, Sakhalin, the Sea of Japan and the Yellow Sea. Pipeline construction has been recently highlighted as an important means of transporting gas and oil. The South Korean and Russian governments have begun talks on the construction of a pipeline from Yakutia through the Russian Far East, North Korea, and South Korea and on to Japan across the Strait of Tsushima.

2. How to expand regional trade and investment. Is it possible to increase international trade and foreign investment by establishing a Northeast Asian economic region or sphere among the countries in this region? Many think that this idea of forming an economic region circumscribed by a geographical border is inappropriate. We believe that the proper type of economic cooperation is one that avoids closed, discriminatory and protectionist integration among member countries and that pursues an open, non-discriminatory, liberalized form of economic community where each country cooperates to promote freer trade and investment flows among member countries and with the outside world as well.

Economic liberalization is growing apace in Northeast Asia. Japan and South Korea are beginning to open up their domestic markets. China is gradually moving from a command to a market-driven economy. The Russian Far East is trading more with Asia-Pacific countries because high railway tariffs make its trade with the European part of Russia too expensive. Mongolia and North Korea are attempting to attract foreign investment, with North Korea going so far as to set up a special economic zone along its northeastern coast.

3. How to define new roles for Japan, South Korea and China. Some people think that whether Northeast Asia will be able to play a key role in the twenty- first century will depend mostly on those three countries. They must to transform themselves through interaction, each applying pressure where the others need it most. Some Koreans admit that they are well aware of their country's limited ability to contribute to economic cooperation in Northeast Asia. If South Korea cannot supply enough capital and technology, and then most of it will have to be supplied by Japan. As some see it, the Japanese government is reluctant to become the leader of this region, but local governments in Japan facing the Sea of Japan are actively trying to build exchanges with countries in the region.

Many believe that the key to successful cooperation in Northeast Asia is, first of all, that South Korea and Japan come up with a definite vision of economic development and relations in the region, and, second, that they foster an international division of cooperation in line with that vision. 


\section{Mongolia's Perspectives}

Finally, I would like to turn to Mongolia's views and opportunities of economic cooperation within Northeast Asia. Mongolia has some impressive assets to contribute to any regional economic community including the following:

a. Abundant mineral resources

b. Broad opportunities to utilize solar and wind energy

c. A young nation, with $75 \%$ of the people being under 35

d. A high literacy rate of $85 \%$

e. A large livestock economy with 25.4 million head

f. An agricultural area totaling 130 million hectares

g. A geographical bridge between Central Asia and Northeast Asia

$\mathrm{h}$ a location between two huge markets in Russia and China

i. A strong commitment to a market economy and k. a relatively stable political situation

On the other hand, Mongolia also suffers some disadvantages, such as its landlocked location, low population density, and an extreme continental climate. Perhaps the most challenging problem Mongolia faces is the poor state of its transportation facilities. Access to Mongolia is possible only through Russia and China. Thus, goods from other Northeast Asia countries are carried to either Chinese or Russian ports and then transported by rail some 2,000 kilometers to Mongolia. This situation must, of course, be improved by greatly expanding the transportation network.

These factors are obviously not fatal disadvantages for the growth of trade and cooperation between Mongolia and other Northeast Asian countries, because they are easily outweighed by its many assets I cited earlier. Perhaps Mongolia's strongest suit is its unequivocal commitment to a market economy and its policy toward international trade and investment. Joint development projects could be based upon the principle that the developed economies supply the equipment, machinery and materials required for development on a longterm deferred-payment basis and, in turn, are provided over a long period of time with agreed-upon quantities of natural resources from Mongolia.

There is a real opportunity for Mongolia to be involved more actively, efficiently and effectively in regional economic cooperation. Mongolia and other Northeast Asian nations can contribute to that cooperation by using their economic complementarily, by continuing various forms of economic interaction, and by improving the infrastructure through joint efforts. 